\title{
The Impact of Human Resource Practices on Employees' Performance through Job Satisfaction at Saudi Ports Authority Based on the Assumption of Maslow Theory
}

\author{
Mohammed Saud Mira, Yap Voon Choon, Chan Kok Thim
}

\begin{abstract}
Saudi Ports is one of the busiest seaports in the world and the biggest ports in the Middle East.It has the largest and most diversified economy in the Middle East with industrial exports that are internationally oriented. The Port Authority played a great role to increase the economics of the country through, cargo handling Imports and exports goods. Saudi Ports Authority has nine main ports on the two cost of the kingdom which achieved $95 \%$ of export and imports goods through the kingdom's seaports while 55\% of the cargo handled is exported. however, cargo's over stock is the main issue that recently came up which raise the price of cargo's handle up to $200 \%$, which as a result of lack of job satisfaction among employees in cargo section and lack appropriate human resource practices. Therefore, our study takes a step to examine the role of human resource practice on employee's performance and also the mediating role of job satisfaction in the relationship between human resource practices and employee's performance in Saudi Port Authority. Moreover, this study will validate of the assumption of Maslow theory. This study will be based on primary data (survey Questionnaire)
\end{abstract}

Keywords: Human Resource Practices, Job Satisfaction, Employees' Performance, Maslow Theory, Cargo Section, Saudi Ports Authority.

\section{INTRODUCTION}

The Kingdom of Saudi Arabia is the world's main oil exporting country. It has the largest and most diversified economy in the Middle East with industrial exports that are internationally oriented. The Port Authority played a great role to increase the economics of the country through, cargo handling Imports and exports goods. According to Elentably (2015), Saudi Ports Authority has nine main ports on the two cost of the kingdom which achieved 95\% of export and imports goods through the kingdom's seaports while $55 \%$ of the cargo handled is exported. In addition, More than 5 million Twenty-Foot Equivalent Unit (TEUs) are handled annually and 11,000 ships visit Saudi ports annually (Elentably, 2015). Despite the positive contribution to GDP of Saudi Arabia, however, cargo's over stock is the main issue that recently came up which raise the price of cargo's handle up to $200 \%$, which as a result of lack of job

Revised Manuscript Received on April 19, 2019.

Mohammed Saud Mira, Department of management, Faculty of management, Multimedia University (MMU), Persiaran Multimedia, 63100 Cyberjaya, Selangor, Malaysia.(Email: merah3000@ hotmail.com)

Yap Voon Choon, Department of management, Faculty of management, Multimedia University (MMU), Persiaran Multimedia, 63100 Cyberjaya, Selangor, Malaysia. (Email :vcyap@mmu.edu.my)

Chan Kok Thim, Department of management, Faculty of management, Multimedia University (MMU), Persiaran Multimedia, 63100 Cyberjaya, Selangor, Malaysia.( Email: ktchan@mmu.edu.my). satisfaction among employees in cargo section (Arab News, 2016).

Al-Bassami pointed out that low job satisfaction enhances low employee performance which as result of lack of appropriate and adequate Human resource practice in cargo field at Saudi Ports Authority (Arab News, 2016). Though there are several kinds of literature on the role of human resource practice on employee job satisfaction and performance (Jeet\& Sayeeduzzafar,2014), it, however, appear to be very limited effect research on the importance of human resource practice on satisfaction and performance of the employee in Saudi port Authority (Elentably, 2015). Therefore, this paper intends to test the impact of human resource practice on employees' performance through job satisfaction at Ports Authority especially in cargo's field.

\section{LITERATURE REVIEW}

\section{Human Resource Practices:}

When the global market becomes more challenge and unstable, many organizations are focused on human resource practices to overcome the challenge and gain the competitive advantage (Berisha and Kutllovci, 2015). Human resource practice is a method to enhance the skills, knowledge, creation, synergy, commitment, and outcome of the organization. Therefore, human resource practice is a core to achieve the goal of the organizations in different fields (Harter, Schmidt \& Hayes 2002; Cania,2014).In addition it is a system that set the attitude and behaviour of the workers, besides build up the relationship between employer and employees which inspire the employees to spend more effort based on creation and innovation that lead the firm to achieve the goal, Thus it motivates the employees(Tan \& Nasurdin 2006, p. 156). Business field is more development and rapidly changes, therefore, that kind of challenges can be defeat by human resource practices through offer different practices which increase the satisfied of the workers, so they will spend more effort to achieve the main goal of the organization. Those practices offer a success to the organization through people (Armstrong 2006, p. 8). Human resource function include many 
practices such as training and development, reward, job analysis, recruitment and selection, employee relationship, employee empowerment and social support, all those practices should be built upon coherent system within clear role of each one, in order to achieve high level of satisfaction and performance of workers (Dessler, 2007; Majumder, 2012; Jeet\& Sayeeduzzafar,2014; Albrecht et al,2015; Hassan,2016)

\section{Human resource practices and Employees' Performance:}

The empirical studies is considered as a rich of literature that indicates the link between human resource practices and performance (Gerhart and Milkovich, 1992; Arthur 1994; Huselid 1995; MacDuffie, 1995; Guest, 1997, Munjuri, 2011; Tabiu \& Nura, 2013; Haddock et al,2016), those studies have been carried out in different sectors in different countries, most of those empirical studies reveal that there is positive relationship between human resource practices and employees' performance (Munjuri, 2011; Tabiu \& Nura, 2013). Therefore, human resource practices offer a role to increase the performance of the employees, which lead the organizations to achieve their sustainable competitive advantage. Thus, the organization should consider the human resource practices as a core method to achieve their goal through employees' performance (Hassan, 2016). According to Boselie et al. (2005) stated that human resource management (HRM) was tested as a set of human resource practices in 104 studies. Human resource practices have seven factor that offers positive contribute to employees' performance, those factors are training and development, reward, job analysis, recruitment and selection, social support, employee relationship and employee empowerment (Delery \& Doty,1996; Nataraja \& Alamri,2016). Consequently, Organisation seeks to select the right persons that have the skills and ability to offer successful environment through those factors (Pfeffer,1994; Cania,2014, Aliyu and Marthandan, 2017). The managers at each organization should imply the practices of human management in a right way because the success of human resource practices is based on the way of implementation. Thus, managers should pay high attention once they intend to imply human resource practices to avoid any mistake that causes a failure (Guest, 2011; Guest, 2017). Although there are many empirical studies that test the relationship between human resource practices and employee's performance in different fields (Korde \& Laghate,2015; Shakeel\& Lodhi,2015). In addition, test the impact of human resource practice on another facet of employee behaviour such as loyalty, engagement etc.(Si\& $\mathrm{Li}, 2012)$. However, there is a limited of studies of the impact of human resource practices and employees' performance at Saudi Ports Authority, especially in cargos' section. Therefore, this study fully examines the role of human resource practices on employees' performance at Saudi Ports Authority, especially at cargo's section.

\section{Human Resource Practices and Job Satisfaction:}

Human resource practices is a method that offer satisfaction to the employees regard to their work at different field of works (Ting, 1997; Bekru,2017), in addition many scholars reveal that human resource practices offer positive contribution to employees' satisfaction at different sectors of organisation which cause high performance of workers (Appellbaum et al, 2000) GouldWilliam (2003) carry out a study at local government organizations in the United Kingdom (UK) to test specific HR practices. The result of the study shows that Human resource practices offer a positive contribution to job satisfaction thus, the workplace trust, commitment, engagement, performance will increase, therefore organization will gain their goal. The human resource practices should be considered by managers as a method that improves the work condition and increases the outcome of the organization (Absar et al,2010). Although, there are empirical studies of human resource practices and job satisfaction at different sector and rich of literature that present the impact of human resource practices on another dependent variable such as performance, loyalty, engagement (Balozi \&Abdullah,2014; Chaudhary \& Bhaskar, 2016; Al-Khasawneh,2013; Tabiu \& Nura, 2013).However, there is limited of studies that present the impact of human resource practice on job satisfaction at Saudi Ports Authority, especially in cargo's section. Therefore, this study fully examines the role of human resource practices on employees' job satisfaction at Saudi Ports Authority especially at cargo's section

\section{Job Satisfaction and Performance}

The relationship between job satisfaction and employees' performance is important and it is an aspect of organizational psychology (Bakotić,2015). Therefore, many researchers did studies to test the relationship between job satisfaction and employees' performance in different sectors (Judge, Thoresen, Bono, \& Patton, 2001). Job satisfaction is the Holy Grail of organizational psychology (Landy, 1989; Mitchell et al,2017). The relationship between the attitude of workplace and outcome of employees' behaviour still an interested area of researchers which present the stem from the Characteristic organisation and social psychological theory (Harrison, Newman, \& Roth, 2006; Schleicher, Watt, \& Greguras, 2004; Lawler \& Porter, 1967; Wicker, 1969). Job satisfaction is the feeling of the employees toward the workplace situation (Smith, Kendall \& Hulin, 1969, p. 6) More recently, job satisfaction presents the thoughts and feeling of employees regard to their jobs. According to Brief and Wesis (2002), job satisfaction can be measured based on the feeling and emotion of employees toward their job condition.

Job performance, on the other hand, is the behaviour of employees that present while they do their job in order to achieve the goal of the organization, this behaviour is visible (Campbell, McHenry, \& Wise, 1990). The organization is focused on their employee's performance, which considers as the main method to achieve the goal of the organization (Hunter \& Hunter, 1984). The definition of performance should be focus on the behaviour of the workers not to the outcome of the organisation, in another word, interested in the outcome of the organisation rather than the behaviour of 
employees will lead the worker to find easiest way to gain the goal of the organisation which may cause negative issue to the organization because desirable behaviour did not perform. Campbell, McCloy, Oppler, and Sager (1993) mention that performance is an observed behaviour of employees during their task and duties. Thus, job satisfaction is an important factor that offers a positive contribution to employees' performance (Gosselin, 2005; Yvonne et al,2014). Despite many empirical studies done in the different field to test the impact of job satisfaction on the performance of employees and to test the impact of job satisfaction on another dependent variable such as engagement, loyalty etc (Owusu,2014 Bakotić,2015; Ram,2013;Davar\&RanjuBala,2012; Abraham,2012; Waqas,2014) However, in the context of Saudi Ports Authority, there is a limited of studies that explore the impact of job satisfaction on employees performance especially cargos' field. Therefore, this study fully examines

\section{Job Satisfaction as Mediator}

Job satisfaction has a positive impact on employees behaviour which leads to increase the commitment, performance, loyalty, and engagement, on the other hand, the rate of turnover, accidents, grievances, tardiness and absenteeism will decrease (Aliyu and Mathandan, 2017; Rothenberg et, 2017). Job satisfaction contributes significantly to employees' performance (Khan el, 2016). resource such as reward, training and development, recruitment and selection to the employees to increase their performance. However, if the employees did not feel satisfy regard to those practices, the performance will decrease. Thus, human resource practices is a facet of job satisfaction, that leads the employees to increase their performance (Koedel,2017). Therefore, managers should pay high attention regard the way of offering practice in order to gain a high level of satisfaction which leads the workers to spend high effort. Although, there are many empirical studies that show the positive relationship between human resource practices and performance through job satisfaction at different field beside test a job satisfaction as a mediator between human resource practices and another outcome (Khan et al., 2016; Nabi,2017).However, there is a limited of studies that present the role of job satisfaction as mediator in public sector in Saudi Arabia especially Saudi ports authority. Therefore, the study will examine the role of job satisfaction as mediator between human resource practices and employees' performance at Saudi ports authority especially at cargo section

\section{Underpinning Theory:}

\section{Maslow Hierarchy Theory}

Maslow's (1943) theory of human motivation is the first theory that considers the needs of growth, fulfilment, and development as the main thing foremployees in term of their Psychology, therefore, he rewarded as a father of humanistic psychology (Anderson,1998) Humanistic psychology is an important field that each organization should focus on it in order to grow the personality of the the role of job satisfaction on employees' performance at Saudi Ports Authority especially at cargo's section The organization offer varieties practices of the human

employees Thus, Maslow considers it as a third force of Psychology following behaviourism and psychoanalysis. Going back to the original source of his theory (1943), Maslow suggests a model of human motivation. Firstly, Maslow supposes that the person needs the special environment and a unique complement of needs at birth which will guide him/her to grow up in a healthy environment. the genes and culture are two determining factors that determine the behaviour based onMaslow's viewpoint (Ryckman, 2000).On the other hand, if the environment was not healthy, restrict the chance of growing and reduce the opportunity for employees to achieve their needs and the neurotic ways of dealing with the issue. In addition, Maslow declares that there are five levels of needs, those levels are a hierarchy. The basic level of needs called Physiological needs, it includes such as sleep, rest, food, and sex. The human body can be present in two categories, which are Homeostasis and body reaction regard to the lack of chemicals in the body. Homeostasis means that once the body receives a normal quantity of water, salt, sugar, protein, and temperature a normal stream of blood will maintain. On the other hand, lack of those or chemicals in the body will lead the person to create a special hunger or appetite for this lack. Thus, the basic needs or the Physiological needs is important to the human in order to move to another level of needs (Maslow, 1943).

The next needs of humanity are safety which includes fairness, physical and psychological safety, security and predictability, once those determinations of safety are not meet the satisfying level, then the bad attitude, behaviour, envy, low level of psychological beside the injury at work will be as a result. Therefore, Maslow urges the organizations to offer safety and healthy work condition to their employees which will decrease the level of those results (Maslow, 1943).

The third level of Maslow's hierarchy of needs is Love and Belongingness Needs, at this level employees are looking to work at good environment that offers good relationship such as support their employees whether by tangible or non-tangible compensations, right of communication between all levels, offer tolerance and advice between each other, thus the employees will feel of loving which lead them to feel that there are a part of the organisation, in another word, they will work at the organisation within considered it as a second home (Maslow, 1943).

Esteem Needs are the fourth set of human needs based on Maslow's hierarchy. This need is based on the appreciation, respectful and autonomy at work, once those factors offered at work, the employees can spend more effort within the feeling of self-worth, strength, capability and the adequacy of being useful to the world.

Maslow (1946) mention that there are two types of esteem needs that offer motivation to the workers, the first one is based on the respectful between workers in order to satisfy ego needs which result in those three which are feelings of self-confidence, capability and adequacy emerge, the second 
is respect that we give to our selves, in another word, selfesteem which is guide the employees to feel of dignity, value and masterful at their job (Rowan, 1998).

Self-Actualisation is the top needs of humanity based on Maslow's hierarchy of needs, at this level, employees feel that they can do everything such as solving the problem, acceptance of facets, create or innovate a new method beside feeling of morality, lack of prejudice and free of restriction (Maslow, 1943).

According to Maslow,(1943) the last level of needs which is self-actualization is not the end of the process but it is an ongoing process, some of the workers achieved and the other is not able to achieve it. Thus Maslow presents some studies of person lives that achieved the highest level of the theory. Some of those people had been interviewed by Maslow, on the other hand, some of them were mention in history books a figure, for example, Thomas Jefferson and Ludwig van Beethoven, in addition, some of them were as luminaries, for instance, Eleanor Roosevelt and Albert Einstein, whose lives had been studies through means of historical and other documents (Gleitman, 1991).

The patterns identified between these characters were been observed such as accepting themselves and others, being unprompted, prefer to have friendly relationship with a few people rather than surface friendship with many people, offer catering to the problem through working on it than themselves (op cit. p.735). Maslow (1991) intent to explain why there are a few people gained the highest level of hierarchy which is self-actualisation, through present the concept of Jonah Complex . Jonah Complex defined as one's fear of his/her greatness. Maslow declares that many people prefer to be seen as an average person rather than show their greatness. Maslow built up those five levels of hierarchy needs, that include motivation of human in his original writing, however, the last level which called selfactualization has been written later during his life.

The needs of human were arranged at an ordinal level based on the Maslow's theory, however, those levels cannot motivate the employees unless they feel satisfied with the basic one, before reaching the second level, in another word, the satisfaction is most important to the employees and without satisfaction, these levels of needs cannot offer motivation or be sufficient to the employees (Maslow, 1943). Designed with the basic level of need which is physiological needs, that include water, home, sex, food, etc. Feeling satisfied at the basic level will guide the employees to join the second level of need which is security and so on. for example, employees feel satisfied to with the basic level, such as got full of food and water, live at home and do sexual relationship, etc it means that the basic level is achieved. Thus, the second level of needs will be the next step. Maslow, state that once A want is offered, then it is no longer want. In another word, the Unwanted level of Maslow's theory does not organize the behaviour of the worker, however, the need level of Maslow's' organize the behaviour level of the employees (Maslow, 1943).

Maslow's theory is distinguishing to theories of motivation in tow concepts which are deprivation (an unsatisfied need) and gratification (a satisfied need).those two concepts determine the behaviour. The deprivation (an unsatisfied need) present in negative behaviour and gratification present in positive behaviour. The five-level of needs based on Maslow's theory is divided into two levels which are deficiency needs or D-needs and being need or Bneed. The deficiency needs or $\mathrm{D}$-needs include all four levels, at the deficiency, needs human will not feel satisfied unless they were deprived. in , addition, once they feel satisfied at the previous level, feeling of deprivation will appear to the next level. On another hand, needing or Bneed which include the last level, which is called Selfactualisation, it is the last level that the employees can reach, within feel full motivation and satisfied (Smith,2003). A cycle of motivation, support employees to be satisfied with their work, is ongoing and never reach ending beside it is varied, complex and fluctuating. Thus, theories of human motivation should be aware of it (Smith,2003; Upadhyaya; 2014; Osman et al,2017)

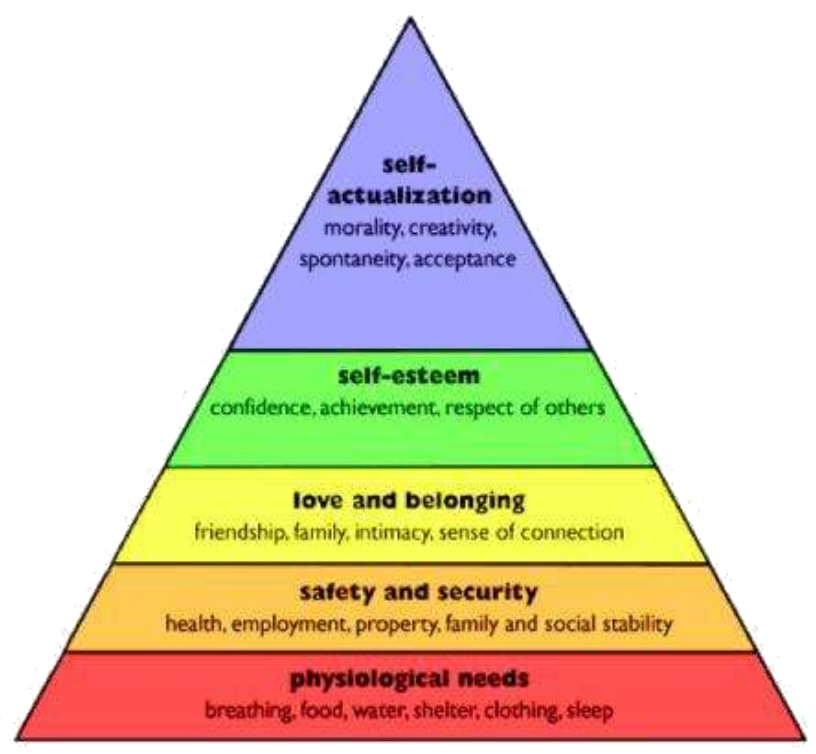

Fig.1: Maslow's Need Hierarchy (Maslow, 1965)

\section{IMPACTS AND IMPLICATION OF HIERARCHY OF NEEDS THEORY ON HUMAN RESOURCE MANAGEMENT}

Human resource management is an important function of each organization in order to achieve the goal of the organization. There are many theories explained how to motivated workers at the workplace in order to gain a high level of performance and productivity which increase the rate of profit of the organization. Maslow's Hierarchy of needs is one of those important theories. Human resource management include different organizational function which present theories and idea from several fields such as management, psychology, sociology and economics (Storey, 1992), which is intended to increase the outcome of employees at workplace (Bratton \& Gold, 2001), human resource management include activities that related to selection , recruitment , orientation, planning , training, compensation and appraisal motivation (Storey, 1992). Robbins and Judge (2009) indicate that human resource 
management has five main functions which are managing conflict, motivating, staffing, disciplining, and training. Likewise, Storey (1992) mention that human resource management has five functions, namely as staffing, rewards, employee development, employee maintenance and employee relations. Those functions are positively influenced by Maslow theory. Malone and Lepper (1987) indicate that leadership at the organization can build up a motivational environment through challenge motivation, Competition motivation, Cooperation and recognition motivation. Hierarchy of needs present five level, those five level is ordinary, in another word, once the first level met the second level will be the next. Those five levels are Physiological needs. Safety needs Social needs, Esteem needs and Self-actualization needs. Physiological needs present in food, water, home, sex, thus the organization should offer practices that meet the first level. Safety needs, the workplace should be safe in order to gain the goal of the organization, therefore the organization should offer helmet and warning system at construction place, in addition, safety need could be present in security of financial. Once the employees feel that they will work at the company without any threat of resigning and decrease of his/her salary. Then the rate of leave will decrease. Social needs, employees at the workplace should feel that they are work as one team without any discrimination, besides they should get sufficient time to spend their life with their families. Esteem needs, leaders should reward or recognize their workers based on their achievement. The reward could be financial such as increase salary or non- financial such as praise thus the workers will be valued. Self-actualization needs, at the last stage employees, can release their potential power in term of creation and innovation. Human resource practices were applied at different organization based on the assumption of Maslow theory which lead the employee to feel valued to their organization thus the level of their satisfaction and performance increased (Ameke,2016; Razak \& Majid,2017).However, there is a limited of studies based on apply the human resource practices due to the assumption of Maslow theory at Saudi port authority especially cargo section.Thus, the study intend to examine the impact of human resources practices on employees' job satisfaction and performance at Saudi port authority especially cargo section

\section{Maslow Theory and Performance:}

Maslow's theory of needs (1956) declare that the needs of a human are hierarchical based on five levels, those levels are (physiological needs, security needs, social needs, selfesteem needs and self-actualization needs). The employees must be satisfied at each level before reaching the highest level which is self-actualization needs, in another word, once the first level is fulfilled, the second level will be the next aim (Zalenski \& Raspa, 2006; Osman et al, 2017). Organisations focus on their employees' performance to gain the success. Employees performance is the act, duty, responsibility that spend by the employees in determined time and cost to achieve or complete the task, it is an important issue to the organization Ray (2016) state that motivations offer positive impact to employees performance once it met the assumption of Maslow theories. Therefore, organizations focus to remain their employees within a high level of performance through offer different practices of human resource management to fill the psychological needs of employees (Oh \& Kuchinke, 2017).

\section{Maslow Theory and Job Satisfaction:}

job satisfaction is one of the most variables that has been researched in the area of workplace psychology (Barriball, Zhang \& While, 2012) and has been related to Psychosocial issues which is concerning to organizational factors which extend from leadership to job design (Spector, 1997; Prajogo et al,2017).

Job satisfaction the popularity relationship of job satisfaction within occupational and organizational as a field of psychology (Spector, 1997; Prajogo et al,2017), many scholars and practitioners have built out their own definition of job satisfaction. However, there are two common definitions that correctly describe job satisfaction. Job satisfaction is the emotional feeling of the employees toward to their jobs (Locke,1976) and the level of satisfaction and dissatisfaction of workers toward their jobs (Spector,1997).

Job satisfaction theories present a strong relationship with motivation theories which explain human motivation. The most known theories are Maslow's needs hierarchy theory (Maslow,1995), Herzberg's (Herzberg,1966) motivatorhygiene theory, the Job Characteristics Model (Hackman \& Oldham,1975) and the dispositional approach (Judge \& Lanen,2001). This study focuses on the link between job satisfaction and Maslow theory.

Although those theories are commonly known in the literature of human motivation, Maslow's needs hierarchy theory is one of the first theories that indicate to test the important contributors to job satisfaction (Maslow, 1995). Maslow's theory suggests that human needs include a fivelevel hierarchy (Figure 1) those five are ordinary from down to top: physiological needs, safety, belongingness/love, esteem, and self-actualization, each level of needs should be achieved before move to the next level (Maslow, 1995).

Maslow's needs hierarchy was built up to demonstrate human motivation in general. However, Maslow's theory is suitable to the work setting within explaining the job satisfaction. The organization should meet the need of their workers from the basic level to the fifth level. financial compensation, tangible reward and health care insurance are one of the most important factors that lead the employees to meet the basic level which is physiological needs. safety level is the second needs of human it achieved through job security , clear policy of organisation beside feeling physically safe at work, once employees feel satisfied at this level, a third level which is feeling of belonging to the workplace will be the next, at this level, employees feel there is strong relationship between all level of workers in term of working as a group, offer tolerance and advice among the employees(Maslow, 1995) . The fourth level which called self-esteem, at this level the employees feel that they are valued and to their organization and appreciated by their colleagues. Finally, self-actualized, employes are tried to show all their ability, skills and

Blue Eyes Intelligence Engineering

\& Sciences Publication 
creativity in order to be a part of everything that able to become. Although it seems to be as ordinary steps from the button to the high level, all of those steps are contribute to the fifth level. Therefore, the organization is focusing on employees' job satisfaction as the main factor that should meet each level before reach the fifth level, which considered as highest level (Maslow, 1995). Pham (2016) present that once employees feel satisfy based on their psychology needs due to the practices that offered by organization, their performance level will increase. Therefore, organization should offer high attention to practices in order to gain high level of employees satisfaction in term of meet the psychology needs( Emu \& Umeh,2014; Mat et al, 2017).

\section{METHODOLOGY:}

This study is correlation study, which means that seek to find out whether two variables are correlated or not in another word whether the increase or decrease in one variable correlates with the decrease or increase in the other variable (Kumar \& Phrommathed 2005) beside it is a crosssectional study which is a research period, that focuses on carrying out a research in short time in order to measure the result that came out from the given respondents (Levin, 2006).In addition, the research approaches are deductive and positivist. Moreover, The Primary data on all the variables will be obtained using survey questionnaires, especially five Likert questionnaires Which is a famous approach based on single rating (Davidson, 1979) and it is considered as the easiest way to collect the data (Haque \& Taher, 2008; Yu \&Egri, 2005).Therefore, this study is a quantitative study (Absar et al, 2010)

\section{Conceptual Framework:}

The objective of the study is to examine the relationship between human resource practices such as (training and development, reward, job analysis, recruitment and selection, social support, employee empowerment and employee relationship ) on employees' performance through job satisfaction the literature of human resource practices reconcile the role of human resource practices on employees' performance (Nassazi, 2013.) In addition, this is in line with Maslow theory that employees are satisfied when there need are fulfilled (Maslow,1965; Khera, 2015)For instance, empirical studies found a positive relationship between human resource practices and employees' job satisfaction (Balozi \& Abdullah,2014; Manzoor et al,2015.)Moreover, the literature indicates that there is a significant association with employees' performance through job satisfaction (Snell \& Bohlander, 2013).

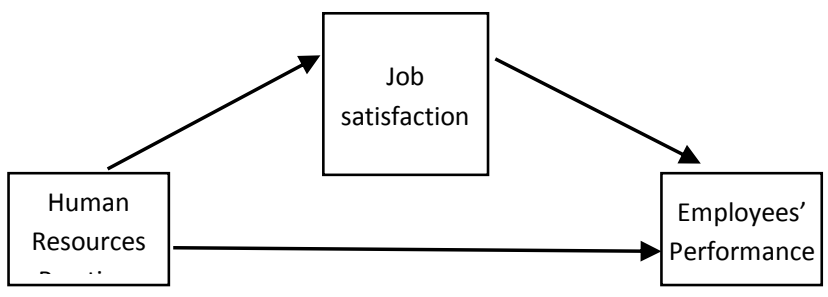

Fig.2 Conceptual Frame Work
Following the conceptualization of Maslow theory that needs of the employee must be fulfilled to have a greater positive outcome. Therefore we assume that human resource practices (Training and development, reward, job analysis, recruitment and selection, social support, employee relationship and employee empowerment ) will have a positive relationship with job satisfaction and performance, in addition, we assume that employees satisfaction will offer significance contribution in the relationship between human resource practices and employees performance beside, we assume that job satisfaction offer positive contribution to employee performance. Based on the figure above (figure 1) our proposition as follows:

P1: There is a positive relationship between human resource practices and employees' performance

P2: There is a positive relationship between human resource practices and job satisfaction

P3: There is a positive relationship between job satisfaction and employees' performance

P4: There is a positive role of job satisfaction as a mediator between human resource practices and employees' performance

\section{CONCLUSION}

This study examines the role of human resource practices on employee's performance and satisfaction in Saudi Arabia port Authority. Human resource practice plays a great role to lead the organisations to achieve competitive advantage and compete in a global dynamic market. The previous literature acknowledges that human resource practice offers positive contributions to employees' loyalty, satisfaction, engagement and performance (Aliyu \&Marthandan, 2017;Nwachukwu \& Chladková ,2017 Aktar \& Pangil,2017; Sutanto\&Kurniawan, 2016; Bustamamet al, 2014). Thus, the needs of employees have to be fulfilled in order to be satisfied and as well to perform (Kuppuswamy et al, 2017). Saudi Ports Authority is very important for the economic growth. However, the current challenges of Saudi Ports Authority are the overstock of cargo which is as a result of low satisfaction and performance of workers at cargo field. According to (Arab News, 2016) lack and appropriate human resource practices is one of the major reason for these challenges. Even though these challenges were addressed in the literature, however, there is a limited study that tests the relationship between human resource practice, job satisfaction and employee performance, more specifically in Saudi Cargo. Therefore, our study takes a step to examine the role of human resource practice on employee's performance and also the mediating role of job satisfaction in the relationship between human resource practices and employee's performance in Saudi Port Authority. 


\section{REFERENCES}

1. Abraham, S. (2012). Job Satisfaction as an Antecedent to Employee Engagement. SIES Journal of Management, $8(2)$

2. Absar, M. M. N., Azim, M. T., Balasundaram, N., \& Akhter, S. (2010). Impact of human resources practices on job satisfaction: Evidence from manufacturing firms in Bangladesh. Economic Sciences Series, 62(2), 31-42.

3. Akilu, N. S., \& Junaidu, A. S. (2015). The Intersection of Self-Actualization, Entrepreneurship and Transformational Leadership: A Review of Maslow's Perspective of Eupsychian Management. American Journal of Trade and Policy, 2(2), 93-100.

4. Aktar, A., \& Pangil, F. (2017). The relationship between employee engagement, HRM practices and perceived organizational support: Evidence from banking employees.

5. Albrecht, S. L., Bakker, A. B., Gruman, J. A., Macey, W. H., \& Saks, A. M. (2015). Employee engagement, human resource management practices and competitive advantage: An integrated approach. Journal of Organizational Effectiveness: People and Performance, 2(1), 7-35

6. Alenezi, O. Y. (2017). Exploring Job-related Attitudes at Northern Boarder University in Saudi Arabia. International Journal of Educational Sciences, 17(1-3), 29-40.

7. Al-Khasawneh, A. L. (2013). The Relation between Human Resource Management (HRM) Strategies and Job Loyalty as Practiced at the Public Relations (PR's) Units in the Government Ministries of Jordan. Journal of Management Research, 5(3), 146-168.

8. Ameke, V. Y. (2016). The Effect of Operational Efficiency on Customer Satisfaction: The Case of Port of Tema (Doctoral dissertation, University of Ghana).

9. Antonellis Jr, P. J., \& Flam, D. (2016). Phoning it in? Examining pre-employment phone interview procedure in higher education. International Journal of Human Resource Studies, 6(1), 21

10. Arab News. (2016). Jeddah Port Crisis Worsens; Transport Fees Rise $200 \%$. Retrieved from http://www.arabnews.com/news/456005

11. Armstrong, M. (2006). A handbook of management techniques: A comprehensive guide to achieving managerial excellence \& improved decision making. Kogan Page Publishers.

12. Arthur, J. B. (1994). Effects of human resource systems on manufacturing performance and turnover. Academy of Management journal, 37(3), 670-687.

13. Bakotić, D. (2016). Relationship between job satisfaction and organisational performance. Economic researchEkonomska istraživanja, 29(1), 118-130.

14. Balozi, M. A., \& Aman, K. D. (2014). The Effect of Training and Development and Employee Relations on Job Satisfaction: A case study of Tanzania Public Service College. Asian Journal of Research in Business Economics and Management, 4(4), 153-161.

15. Bekru, E. T., Cherie, A., \& Anjulo, A. A. (2017). Job satisfaction and determinant factors among midwives working at health facilities in Addis Ababa city, Ethiopia. PloS one, 12(2), e0172397.

16. Berisha Qehaja, A., \& Kutllovci, E. (2015). The role of human resources in gaining competitive advantage.

17. Boselie, P., Dietz, G., \& Boon, C. (2005). Commonalities and contradictions in HRM and performance research. Human resource management journal, 15(3), 67-94.

18. Brief, A. P., \& Weiss, H. M. (2002). Organizational behavior: Affect in the workplace. Annual review of psychology, 53(1), 279-307.

19. Bustamam, F. L., Teng, S. S., \& Abdullah, F. Z. (2014). Reward management and job satisfaction among frontline employees in hotel industry in Malaysia. Procedia-Social and Behavioral Sciences, 144, 392-402.

20. Campbell, J. P., McCloy, R. A., Oppler, S. H., \& Sager, C. E. (1993). A theory of performance. Personnel selection in organizations, 3570, 35-70.

21. Cania, L. (2014). The impact of strategic human resource management on organizational performance. Economia. Seria Management, 17(2), 373-383.

22. Chaudhary, N. S., \& Bhaskar, P. (2016). Training and development and job satisfaction in education sector. Training and Development, 2(8).

23. Chiedu, C. K., Long, C. S., \& Ashar, H. B. (2017). The Relationship Among Job Satisfaction, Oreganizational Commitiment and Employees' Turnover at Unilever Corporation in Nigeria. European Journal of Multidisciplinary Studies, 5(1), 370-383.

24. Davar, S.C. \& RanjuBala (2012). Relationship between job satisfaction \& job performance: A meta-analysis. Indian journal of industrial Relations 48 (2), 290-305.

25. Davidson, W. L. (1979). How to develop and conduct successful employee attitude surveys. Dartnell.

26. Delery, J. E., \& Doty, D. H. (1996). Modes of theorizing in strategic human resource management: Tests of universalistic, contingency, and configurational performance predictions. Academy of management Journal, 39(4), 802-835.

27. Dessler, G. (2006). A framework for human resource management. Pearson Education India.

28. Dhar, R. L. (2015). Service quality and the training of employees: The mediating role of organizational commitment. Tourism Management, 46, 419-430.

29. Dwarakish, G. S., \& Salim, A. M. (2015). Review on the Role of Ports in the Development of a Nation. Aquatic Procedia, 4, 295-301.

30. Ekwoaba, J. O., Ikeije, U. U., \& Ufoma, N. (2015). The Impact of Recruitment and Selection Criteria on Organizational Performance.

31. Elentably, A. (2015). Strategic and Operational Plan Implementation of Seaports (Utilization Jeddah Port). TransNav: International Journal on Marine Navigation and Safety of Sea Transportation, 9.

32. Emu, K. E., \& Umeh, O. J. (2014). How Leadership Practices Impact Job Satisfaction of Customer Relationship Officers': An Empirical Study. Journal of Management Policies and Practices, 2(3), 19-56.

33. Gerhart, B., Milkovich, G. T., \& Murray, B. (1992). Pay, performance, and participation (CAHRS Working Paper \#92-28). Ithaca, NY: Cornell University, School of Industrial and Labor Relations, Center for Advanced Human Resource Studies.

34. Gosselin, M. (2005). An empirical study of performance measurement in manufacturing firms. International journal of productivity and performance management, 54(5/6), 419-437.

35. Gould-Williams, J. (2003). The importance of HR practices and workplace trust in achieving superior performance: a study of public-sector organizations. International journal of human resource management, 14(1), 28-54

36. Gubler, T., Larkin, I., \& Pierce, L. (2016). Motivational spillovers from awards: Crowding out in a multitasking environment. Organization Science, 27(2), 286-303.

37. Guest, D. E. (1997). Human resource management and performance: a review and research agenda. Internationa journal of human resource management, 8(3), 263-276.

38. Guest, D. E. (2011). Human resource management and performance: still searching for some answers. Human

Published By:

Blue Eyes Intelligence Engineering

\& Sciences Publication

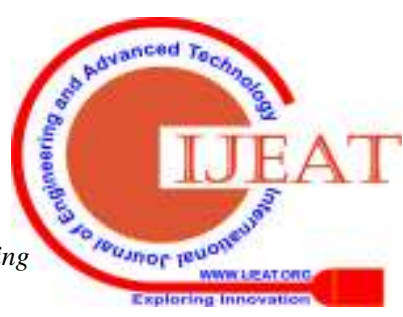


resource management journal, 21(1), 3-13.

39. Guest, D. E. (2017). Human resource management and employee well-being: Towards a new analytic framework. Human Resource Management Journal, 27(1), 22-38.

40. Guest, D. E. (2017). Human resource management and employee well-being: Towards a new analytic framework. Human Resource Management Journal, 27(1), 22-38.

41. Hackman, J. R., \& Oldham, G. R. (1975). Development of the job diagnostic survey. Journal of Applied psychology, 60(2), 159.

42. Haddock-Millar, J., Sanyal, C., \& Müller-Camen, M. (2016). Green human resource management: a comparative qualitative case study of a United States multinational corporation. The International Journal of Human Resource Management, 27(2), 192-211.

43. Haque, M. M., \& Taher, M. A. (2008). Job Characteristics model and job satisfaction: Age, gender and marital status effect. in 7th International Conference on Ethics and Quality of Work-life for Sustainable Development, Bangkok, Thailand.

44. Harrison, D. A., Newman, D. A., \& Roth, P. L. (2006) How important are job attitudes? Meta-analytic comparisons of integrative behavioral outcomes and time sequences. Academy of Management journal, 49(2), 305325.

45. Harter, J. K., Schmidt, F. L., \& Hayes, T. L. (2002). Business-unit-level relationship between employee satisfaction, employee engagement, and business outcomes: a meta-analysis. Journal of applied psychology, 87(2), 268.

46. Harter, J. K., Schmidt, F. L., \& Hayes, T. L. (2002). Business-unit-level relationship between employee satisfaction, employee engagement, and business outcomes: a meta-analysis. Journal of applied psychology, 87(2), 268.

47. Haruna, A. Y., \& Marthandan, G. (2017). Foundational competencies for enhancing work engagement in SMEs Malaysia. Journal of Workplace Learning, 29(3), 165184.

48. Hassan, S. (2016). Impact of HRM practices on employee's performance. International Journal of Academic Research in Accounting, Finance and Management Sciences, 6(1), 15-22.

49. Herzberg, F. I. (1966). Work and the nature of man. Cleveland: World Pub. Co.

50. Hunter, J. E., \& Hunter, R. F. (1984). Validity and utility of alternative predictors of job performance. Psychological Bulletin, 96(1), 72-98.

51. http://dx.doi.org/10.1037/0033-2909.96.1.72

52. Huselid, M. A. (1995). The impact of human resource management practices on turnover, productivity, and corporate financial performance. Academy of management journal, 38(3), 635-672. of work life of Emirati women and its influence on job satisfaction and turnover intention: Evidence from the UAE. Journal of Organizational Change Management, 31(2), 352-370

54. Jain, A. K., \& Moreno, A. (2015). Organizational learning, knowledge management practices and firm's firm in India. The Learning Organization, 22(1), 14-39.

55. Jaiswal, D., \& Dhar, R. L. (2016). Impact of perceived organizational support, psychological empowerment and leader member exchange on commitment and its subsequent impact on service quality. International Journal of Productivity and Performance Management, 65(1), 58-79.
53. Jabeen, F., Friesen, H. L., \& Ghoudi, K. (2018). Quality performance: an empirical study of a heavy engineering

56. Judge, T. A., \& Larsen, R. J. (2001). Dispositional affect and job satisfaction: A review and theoretical extension. Organizational behavior and human decision processes, 86(1), 67-98

57. Judge, T. A., Thoresen, C. J., Bono, J. E., \& Patton, G. K. (2001). The job satisfaction-job performance relationship: A qualitative and quantitative review. Psychological bulletin, 127(3), 376.

58. Khan, A. A., Abbasi, S. O. B. H., Waseem, R. M., Ayaz, M., \& Ijaz, M. (2016). Impact of training and development of employees on employee performance through job satisfaction: A study of telecom sector of Pakistan. Business Management and Strategy, 7(1), 2946.

59. Koedel, C., Li, J., Springer, M. G., \& Tan, L. (2017). The impact of performance ratings on job satisfaction for public school teachers. American Educational Research Journal, 54(2), 241-278.

60. Korde, A., \& Laghate, K. (2015). Is There Any Impact of Training on the Performance of Selected Public Sector Banks?. Symbiosis Centre for Management Studies, Pune Annual Research Journal of Symbiosis Centre for Management Studies, Pune, 3, 135-15.

61. Kumar, S., \& Phrommathed, P. (2005). Research methodology(pp. 43-50). Springer US.

62. Kuppuswamy, N., Saminathan, V., Udhayakumar, M., Vigneash, L., \& Gopalakrishnan, P. (2017). The Role of Motivation on Employee Performance in an Organization.

63. Landy, F. J. (1989). Psychology of work behavior Thomson Brooks/Cole Publishing Co.

64. LAWLER III, E. E., \& Porter, L. W. (1967). The effect of performance on job satisfaction. Industrial relations: A journal of Economy and Society, 7(1), 20-28.

65. Levin, K. A. (2006). Study design III: Cross-sectional studies. Evidence-based dentistry, 7(1), 24.

66. MacDuffie, J. P. (1995). Human resource bundles and manufacturing performance: Organizational logic and flexible production systems in the world auto industry. ILR Review, 48(2), 197-221.

67. Malik, M. A. R., Butt, A. N., \& Choi, J. N. (2015). Rewards and employee creative performance: Moderating effects of creative self-efficacy, reward importance, and locus of control. Journal of Organizational Behavior, 36(1), 59-74.

68. Manzoor, R., Ahmad, N., Hussain, A., \& Hameed, M (2015). Impact of Rewards on Job Satisfaction Evidences from Ttelecom Sector of Pakistan. Oman Chapter of Arabian Journal of Business and Management Review, 34(2610), 1-14

69. Maslow, A. H. (1965). Eupsychian management: A journal. Homewood: RD Irwin.

70. Miraglia, M., Alessandri, G., \& Borgogni, L. (2015). Trajectory classes of job performance: The role of selfefficacy and organizational tenure. Career development international, 20(4), 424-442.

71. Mitchell, M. S., Reynolds, S. J., \& Treviño, L. K. (2017) The study of behavioral ethics within organizations. Personnel Psychology, 70(2), 313-314.

72. Nabi, M. N., Ahmed, A. A. T., \& Rahman, M. S. (2017), The Empirical Study on Human Resource Management Practices with Special Reference to Job Satisfaction and Employee Turnover at Investment Corporation of Bangladesh. Human Resource Management Research, 7(1), 54-64

73. Nassazi, A. (2013). EFFECTS OF TRAINING ON EMPLOYEE PERFORMANCE.: Evidence from 
Uganda.

74. Nataraja, S., \& Alamri, M. S. (2016). Strategic human resource management in Saudi Arabia's service sector. Journal of Competitiveness Studies, 24(1/2), 91.

75. Ng, T. W., Lam, S. S., \& Feldman, D. C. (2016). Organizational citizenship behavior and counterproductive work behavior: Do males and females differ?. Journal of Vocational Behavior, 93, 11-32.

76. Nwachukwu, C. E., \& Chladková, H. (2017). Human resource management practices and employee satisfaction in microfinance banks in Nigeria. Trends Economics and Management, 11(28), 23-35.

77. Ogbogu, C. O. (2017). The effects of motivation on staff job performance: Evidences from the Lagos State Ministry of Environment, Nigeria. Journal of Sustainable Development, 10(2), 183.

78. Oh, S. Y., \& Kuchinke, K. P. (2017). Exploring the role of organizational learning activities in the quality management context. Leadership \& Organization Development Journal, 38(3), 380-397.

79. Osman, M. M., Bachok, S., Abdullah, A., Ibrahim, M., \& Bakar, A. A. (2017). Analysis on the Fulfillment of Hierarchy of Needs for Central Region of Malaysia.

80. Owusu, B., \& Owusu, B. (2014). An assessment of job satisfaction and its effect on employees' pPerformance: A case of Mining Companies in the [Bibiani-AnhwiasoBekwai District] in the Western Region (Doctoral dissertation).

81. Pfeffer, J., \& Villeneuve, F. (1994). Competitive advantage through people: Unleashing the power of the work force (Vol. 61). Boston, MA: Harvard Business School Press.

82. Pham, M. L. (2016). EVALUATING JOB SATISFACTION LEVELS: Case: Truong An Joint Stock Company (TACO).

83. Prajogo, D. I., \& Cooper, B. (2017). The individual and organizational level effects of TQM practices on job satisfaction. International Journal of Manpower, 38(2), 215-225.

84. Purcell, J., \& Kinnie, N. (2007). HRM and business performance. Oxford Handbook of Human Resource Management, The, 533.

85. Ram, P. (2013). Relationship between job satisfaction and job performance in the public sector - a case study from India.International Journal of Academic Research in Economics and Management Sciences, 2(2), 16.

86. Ray, J. (2016). Staff motivation and its impact on performance in a retail environment.

87. Robbins, S. P., \& Judge, T. A. (2018). Organizational behavior (18th ed.). Boston: Pearson

88. Robson, C. (2002). Real world research. 2nd. Edition Blackwell Publishing. Malden.

89. Rothenberg, S., Hull, C. E., \& Tang, Z. (2017). The impact of human resource management on corporate Society, 56(3), 391-418.

90. Rubin, A. and Babbie, E.R. (2016). Empowerment series: Essential Research Methods for Social Work (4th ed.). Boston, MA: Cengage Learning.

91. Rubin, A., \& Babbie, E. R. (2016). Empowerment series: Research methods for social work. Cengage Learning.

92. Schleicher, D. J., Watt, J. D., \& Greguras, G. J. (2004). Reexamining the job satisfaction-Performance relationship: The complexity of attitudes. Journal of applied psychology, 89(1), 165.

93. Shakeel, S., \& Lodhi, S. (2015). Impact of Training and Development on Employee Performance: A Case of Banking Sector of Pakistan. The International Journal of Business \& Management, 3(11), 76. Advanced Science Letters, 23(1), 417-421. social performance strengths and concerns. Business \&

94. Si, S., \& Li, Y. (2012). Human resource management practices on exit, voice, loyalty, and neglect: Organizational commitment as a mediator. The International Journal of Human Resource Management, 23(8), 1705-1716.

95. Snell, S., Morris, S., \& Bohlander, G. W. (2015). Managing human resources. Nelson Education.

96. Sonnentag, S., \& Fritz, C. (2015). Recovery from job stress: The stressor-detachment model as an integrative framework. Journal of Organizational Behavior, 36(S1), S72-S103.

97. Spector, P. E. (1997). Advanced Topics in Organization Behavior: Job satisfaction: Application, assessment, causes, and consequences. Thousand Oaks, CA: SAGE Publications, Inc.

98. Spector, P. E. (1997). Job satisfaction: Application, assessment, causes, and consequences (Vol. 3). Sage publications.

99. Sutanto, E. M., \& Kurniawan, M. (2016). The impact of recruitment, employee retention and labor relations to employee performance on batik industry in Solo City, Indonesia (Doctoral dissertation, Petra Christian University).

100. Tabiu, A., \& Nura, A. A. (2013). Assessing the effects of human resource management (HRM) practices on employee job performance: A study of usmanu danfodiyo university sokoto. Journal of Business Studies Quarterly, 5(2), 247.

101. Tan, C. L., \& Nasurdin, A. M. (2011). Human resource management practices and organizational innovation assessing the mediating role of knowledge management effectiveness. Electronic journal of knowledge management, 9(2), 155.

102. Timms, C., Brough, P., O'Driscoll, M., Kalliath, T., Siu, O. L., Sit, C., \& Lo, D. (2015). Flexible work arrangements, work engagement, turnover intentions and psychological health. Asia Pacific Journal of Human Resources, 53(1), 83-103.

103. Ting, Y. (1997). Determinants of job satisfaction of federal government employees. Personnel Administration, 26(3), 313-334.

104. Waqas, A., Bashir, U., Sattar, M. F., Abdullah, H. M., Hussain, I., Anjum, W., ... \& Arshad, R. (2014). Factors influencing job satisfaction and its impact on job loyalty. International Journal of Learning and Development, 4(2), 141-161.

105. Wicker, A. W. (1969). Attitudes versus actions: The relationship of verbal and overt behavioral responses to attitude objects. Journal of Social issues, 25(4), 41-78.

106. Yu, B. B., \& Egri, C. P. (2005). Human resource management practices and affective organizational commitment: A comparison of Chinese employees in a state-owned enterprise and a joint venture. Asia Pacific Journal of Human Resources, 43(3), 332-360.

107. Yvonne, W., Rahman, R. H. A., \& Long, C. S. (2014). Employee job satisfaction and job performance: A case study in a franchised retail-chain organization. Research Journal of Applied Sciences, Engineering and Technology, 8(17), 1875-1883.

108. Zalenski, R. J., \& Raspa, R. (2006). Maslow's hierarchy of needs: a framework for achieving human potential in hospice. Journal of palliative medicine, 9(5), 1120-1127.

109. Smith, P. C., Kendall, L. M., \& Hulin, C. L. (1969). The measurement of satisfaction in work and retirement: a strategy for the study of attitudes. Chicago, Ill: Rand McNally 